Jurnal Adat dan Budaya, Vol.2, No.1 Tahun 2020

ISSN: E-ISSN 2615-6156, P-ISSN: 2615-6113

Jurnal Homepage: https://ejournal.undiksha.ac.id/index.php/JABI/index

\title{
PENGARUH MODEL PEMBELAJARAN PROBING PROMPTING BERBASIS ETNOMATEMATIKA TERHADAP KOMPETENSI PENGETAHUAN MATEMATIKA KELAS V
}

\author{
Putu Risma Radiana ${ }^{1}$, I Wayan Wiarta ${ }^{2}$, I Komang Ngurah Wiyasa ${ }^{3}$ \\ 123 Program Studi Pendidikan Guru Sekolah Dasar, Universitas Pendidikan Ganesha, Bali, Indonesia \\ E-mail : puturismaradiana@gmail.com
}

\begin{abstract}
Abstrak
Penelitian ini berawal dari hasil observasi dan studi kasus di kelas V SD yang menunjukkan bahwa masih banyak siswa yang belum mencapai KKM dalam pelajaran matematika, selain itu belum diterapkannya model pembelajaran Probing Prompting berbasis Etnomatematika. Tujuan dilaksanakan penelitian ini untuk mengetahui pengaruh yang signifikan model Probing Prompting berbasis etnomatematika terhadap kompetensi pengetahuan Matematika kelas V. Adapun desain dalam penelitian ini yakni Non Equivalent Pretest Postest Control Group Design. Populasi penelitian ini terdiri dari kelas V SD Gugus Letda Made Putra yang terdiri sebanyak 462 orang dari 13 kelas. Sampel ditentukan dengan teknik cluster random sampling, sampel yang terpilih terdiri dari kelompok eksperimen yaitu kelas V SD Negeri 2 Tonja yang dibelajarkan model Probing Prompting berbasis etnomatematika dan kelompok kontrol kelas VB SD Negeri 23 Dangin Puri dibelajarkan secara konvensional. Data kompetensi pengetahuan matematika dikumpulkan dengan instrumen berupa tes objektif. Data yang diperoleh selanjutnya ditentukan GSn kemudian dianalisis menggunakan uji-t. Berdasarkan analisis diperoleh $t_{\text {hit }}(12,696)>t_{\text {tab }}(1,998)$ dengan tingkat kesalahan $0,05 \mathrm{dan} \mathrm{df}=63$. Maka diterimanya $\mathrm{H}_{\mathrm{a}}$. Jadi dapat disimpulkan bahwa terdapat pengaruh yang signifikan model pembelajaran Probing Prompting berbasis etnomatematika terhadap kompetensi pengetahuan matematika kelas V SD Gugus Letda Made Putra Kecamatan Denpasar Utara Tahun Ajaran 2019/2020. Berdasarkan hasil penelitian, penelitian ini dapat dijadikan sebagai hasil kajian yang relevan dan memperdalam mengenai model pembelajaran Probing Prompting berbasis Etnomatematika. Model ini dapat dijadikan bahan guru dalam memilih variasi dalam mengajar dikarenakan sudah terbukti dapat meningkatkan kompetensi pengetahuan matematika.
\end{abstract}

Kata Kunci: Probing Prompting; Etnomatematika; Matematika

\begin{abstract}
This research begins with the results of observations and case studies in class $\mathrm{V}$, which shows that there are still many students who have not yet reached the KKM, especially in mathematics, in addition to that the Ethnomathemics-based Probing Prompting learning model has not yet been applied. The purpose of this research is to discover the significant influence of ethnomathematics-based Probing Prompting models on the fifth-grade Mathematics knowledge competence. The design in this study is Non-Equivalent Pretest Posttest Control Group Design. The population of this study consisted of Class V of the Letda Made Putra Cluster Elementary School, consisting of 462 people from 13 classes. The sample was determined by cluster random sampling technique, the selected sample consisted of an experimental group, namely Class V of SD Negeri 2 Tonja, which was applied to the Probing Prompting model based on ethnomathematics and the control group of Class VB SD Negeri 23 Dangin Puri was conventionally taught. The data of mathematics competency was collected with instrument of objectives test. The data obtained with determines GSn and the next analyse by t-test. Based on the analysis obtained t-value $(12,696)>t$-table $(1,998)$ with an error rate of 0.05 and $d f=63$. Then where Ha. So it can be concluded that there is a significant influence on ethnomathematics based Probing Prompting learning model on the competence of fifth grade mathematics knowledge of Elementary School Letda Made Putra in the North Denpasar District in the Academic Year 2019/2020. Based on the results of the study, this research can be used as the results of relevant and deepening studies of ethnomathematics based Probing Prompting learning models. This research can be used as a reference for the teacher in choose the variation of learning process in class, because the method on this research has been proven to increase the mathematic competence in students grade five
\end{abstract}

Keywords : Probing Prompting; Ethnomathematics; Mathematics 


\section{PENDAHULUAN}

Sumber Daya Manusia (SDM) yang berkelas terbentuk melalui proses primer yakni pendidikan. Menurut Putra (2017) pendidikan merupakan ikhtiar mengarahkan anak dari lahir guna meraih kedewasaan raga dan interlektual. Melalui pendidikan manusia mampu menjadi pribadi yang unggul dalam perbuatan, sikap, serta pemikirannya dan memahami sesuatu yang belum dipahami, dalam pendidikan ini berlangsung sebuah proses interaksi antara pendidik dan peserta didik demi mencapai sebuah tujuan pembelajaran. Berkaitan dengan hal tersebut, di rancanglah sebuah pedoman dalam kegiatan pembelajaran yang disebut dengan kurikulum. Kurikulum yang diterapkan di dalam dunia pendidikan negara ini adalah Kurikulum 2013 (K-13). Pada awal pemberlakuannya di SD, K-13 ini melaksanakan pembelajaran tematik yang terdiri dari bidang studi Bahasa Indonesia, bidang studi PPKn, bidang studi IPS, bidang studi Matematika dan bidang studi IPA. Seiring dengan perkembangan zaman pada tahun 2017, bidang studi PJOK dan Matematika terpisah dari pembelajaran tematik yang dimulai dari kelas IV SD/MI (Permendikbud, 2016)

Salah satu pelajaran yang didapatkan di SD yaitu matematika. Bidang studi ini diajarkan pada semua jenjang pendidikan mulai dari Pendidikan dasar - Perguruan tinggi, bidang studi ini sangat diperlukan dalam kehidupan sehari - hari seperti untuk memecahkan permasalahan yang dan melatih pola pikir dan penalaran dalam memahami objek matematika (Purnamasari, 2018). Adapun alasan mengapa siswa perlu belajar matematika menurut (Krisnayanti et al., 2017) sebagai sarana 1) berpikir secara logis dan sistematis, 2) menyelesaikan permasalahan, 3) dalam membentuk pola, hubungan dan hasil generalisasi pengalaman seseorang, 4) mengembangkan kreativitas seseorang, serta 5) Wahana peningkatan kesadaran adanya adaptasi dan perkembangan budaya. Menurut (Kurniyanthi, 2017). Pelajaran Matematika khususnya di SD diajarkan dengan tujuan memberikan konsep awal kepada siswa untuk mempelajari Matematika pada jenjang yang lebih tinggi, karena pelajaran ini merupakan mata pelajaran yang berkesinambungan.

Indrawan (2018) berpendapat matematika merupakan ilmu terstruktur dengan konsep konsep tersusun sistematis dan logis mulai dari konsep paling sederhana sampai pada konsep paling kompleks. Matematika merupakan disiplin ilmu yang mampu meningkatkan kemampuan memecahkan masalah, berpikir serta berargumen dalam kehidupan sehari - hari (Susanto, 2019). Lebih lanjut menurut (Fitrianti, 2020) matematika adalah merupakan bidang ilmu yang terstruktur dan terorganisasi serta pasti yang terdiri dari unsur yang tidak dapat dijelaskan namun dapat dibuktikan serta diterima secara deduktif

Hasil pembelajaran matematika di SD belum menunjukkan hasil yang memuaskan hal tersebut. dibuktikan berdasarkan hasil Trends in Mathematics and Science Study (TIMSS) yaitu riset internasional mengenai tendensi atau arah perkembangan matematika dan sains beberapa negara di dunia yang rutin diadakan setiap 4 tahun oleh The International for Evaluation of Education Achievement (IEA), didapatkan rata-rata skor Indonesia sejumlah 397 dari 500 yang masih masuk ke kategori rendah (IEA, 2015). Dan diperkuat oleh temuan studi pendahuluan yang dilaksanakan di tanggal 26 hingga 28 Oktober 2019, diperoleh data berupa hasil Penilaian Tengah Semester (PTS) ganjil yang menunjukkan bahwa kompetensi siswa belum memuaskan, dikarenakan nilai siswa masih ada dibawah KKM. Dari 462 siswa kelas V, sebanyak 72,51\% atau 335 siswa belum tuntas, selain banyak siswa yang nilai PTS semester ganjilnya belum tuntas, Hal ini disebabkan oleh kurangnya keaktifan peserta didik dalam proses pembelajaran sesuai dengan kurikulum 2013 (Juwita Dewi, 2020). Rendahnya kompetensi pengetahuan matematuka siswa dikarenakan beberapa permasalahan dalam proses pembelajaran matematika, yakni 1) peserta didik belum berani menyampaikan pendapat ketika diberikan suatu pertanyaan/permasalahan oleh pendidik 2) kegiatan belajar mengajar didominasi oleh pendidik 3) peserta didik kurang memahami konsep matematika karena belum maksimalnya penerapan metode pembelajaran yang inovatif dan penggunaan pendekatan saintifik belum optimal 4) serta pembelajaran matematika belum dikaitkan dengan kehidupan sehari - hari (Arta, 2020). Tidak tuntasnya kompetensi pengetahuan matematika dikarenakan kurang optimalnya penyelesaian soal dan permasalahan yang dihadapi oleh siswa dalam pelajaran matematika. Sehingga sebagian besar kompetensi pengetahuan matematika siswa belum menunjukan hasil yang optimal. Secara teoritis terdapat 2 faktor yang berpengaruh terhadap kompetensi pengetahuan matematika, yaitu faktor internal (berasal dari dalam diri siswa) antara lain intelegensi, minat, perhatian, kegigihan, perilaku, dan kondisi kesehatan, sedangkan faktor berikutnya yaitu eksternal (berasal dari luar diri siswa). yang meliputi lingkungan keluarga, sekolah serta masyarakat (Adnyani, 2020). Dari beberapa faktor yang berpengaruh terhadap kompetensi pengetahuan matematika, diantaranya ialah peranan guru dan 
strategi pembelajaran yang dipergunakan pada saat mengajar. Strategi pembelajaran ialah rencana pelaksanaan belajar mengajar yang guru lakukan bersama siswa untuk mencapai tujuan yang diharapkan. Untuk mengimplementasikan kegiatan belajar mengajar dimanfaatkan berbagai metode serta model pembelajaran

Pada saat peneliti melakukan studi pendahuluan masih terdapat proses pembelajaran matematika yang dilakukan masih terdapat pembelajaran dengan metode konvensional. E. R. Dewi (2018) berpendapat metode konvensional dalam pembelajaran adalah metode yang digunakan dalam kegiatan belajar mengajar keseharian dimana pembelajaran hanya terfocus pada pendidik dan lebih membuat peserta didik menjadi tidak aktif saat kegiatan belajar mengajar Selain itu, permasalahan lain yang ditemukan adalah kurang maksimalnya penggunaan model pembelajaran sehingga siswa menganggap bidang studi matematika sebagai pelajaran yang susah dipahami serta menyebabkan kurangnya minat siswa untuk mempelajari matematika sehingga ini menyebabkan banyak siswa yang nilai kompetensi pengetahuan matematikanya belum tuntas, selain itu matematika yang diperoleh di dalam kelas sangat berbeda dengan yang ditemukan anak dalam kehidupan keseharian. Oleh karena itu diperlukan sesuatu yang dapat menghubungkan antara matematika dengan kehidupan keseharian yang berbasis pada kebudayaan lokal.

Terkait dengan permasalahan tersebut, maka perlu adanya inovasi agar nilai kompetensi pengetahuan matematika siswa lebih baik. Salah satu inovasi yang diharapkan dapat mengatasi permasalahan tersebut yaitu dengan menerapkan model pembelajaran Probing Prompting (PP). PP terdiri dari dua kata yaitu Probing dan Prompting yang masing - masing memiliki arti penyelidikan dan menuntun (Megasari et al., 2018)

Jayanti (2018) menyatakan bahwa PP merupakan suatu model pembelajaran yang bersifat student centered, yang memberikan keleluasaan kepada peserta didik untuk aktif membangun pengetahuannya sendiri sedangkan pendidik hanya menjadi mediator serta fasilitator saat proses belajar mengajar. Menurut (Susanti, 2017) PP merupakan salah satu model belajar dimana saat pembelajaran guru menyuguhkan serangkaian pertanyaan yang bersifat menggali dan menuntun yang menyebabkan terjadinya kegiatan berpikir menghubungkan pengalaman dengan pengetahuan yang sedang dipelajari. Lebih lanjut (Yulia \& Ningsih, 2018) menjelaskan model $P P$ merupakan kegiatan pembelajaran dimana pendidik mengajukan serangkaian pertanyaan yang bertujuan menggali dan menuntun buah pikir peserta didik sehingga dapat melahirkan proses berpikir yang mampu memadukan pengalaman dengan pengetahuan baru yang sedang dipelajari. Berdasarkan paparan tersebut, dapat dirangkum bahwa model $P P$ merupakan kegiatan pembelajaran dimana pendidik menyuguhkan serangkaian pertanyaan yang bersifat menuntun dan menggali yang menyebabkan terjadinya kegiatan berpikir yang menggabungkan pengalaman dan pengetahuan yang sedang dipelajari.

Pembelajaran dengan $P P$ memiliki keterkaitan pertanyaan. Pertanyaan - pertanyaan tersebut dinamakan probing question yang memiliki arti pertanyaan yang bertujuan membimbing siswa guna memperoleh jawaban yang tepat serta memperluas mutu jawaban yang berpengaruh terhadap jawaban selanjutnya agar jelas serta tepat (Aulia, 2019). Kegiatan tanya jawab saat proses pembelajaran dilakukan dengan guru menunjuk peserta didik secara random sehingga setiap peserta didik harus siap untuk ditunjuk. Proses probing dapat membuat peserta didik menjadi aktif dalam belajar, sebab proses ini memerlukan konsentrasi tinggi. Selanjutnya, perhatian peserta didik terhadap pembelajaran yang sedang berlangsung sangat baik karena peserta didik selalu mempersiapkan jawaban jika tiba - tiba ditunjuk oleh guru

Adapun Keunggulan dari model pembelajaran PP, menurut Muthmainnah (2019) yaitu : (1) Memacu siswa agar berpikir aktif, (2) Memberikan kesempatan kepada siswa untuk bertanya tentang materi yang belum dimengerti, (3) Terjadinya perbedaan pendapat antar siswa sehingga terjadi diskusi yang aktif, (4) Pertanyaan yang menarik dapat meningkatkan daya fokus siswa ketika belajar, (5) Mereview kembali pembelajaran sebelumnya, (6) Menambah rasa percaya diri serta keterampilan siswa dalam menyampaikan pendapat dan menjawab pertanyaan.

Dalam pelaksanaannya model pembelajaran PP ini memiliki beberapa tahapan (sintak), Shoimin ( 2017) menguraikan sintak model pembelajaran $P P$ yaitu : (1) Menyatakan informasi yang mengandung masalah, (2) Memberikan waktu berpikir, (3) Memberikan persoalan atau pertanyaan sesuai indikator (probing question, (4) Memberikan waktu berpikir bagi siswa, (5) Memberikan kesempatan untuk siswa menjawab atau ditunjuk oleh guru, (6) Meminta tanggapan siswa lain dengan memberikan pertanyaan serta isyarat penuntun (prompting), (7) Mengajukan pertanyaan akhir. 
Terkait dengan pembelajaran matematika yang belum dikaitkan dengan kehidupan keseharian, diperlukan sebuah inovasi yang mampu mewadahi hal tersebut salah satunya yaitu Ethnomathematics, atau yang sering dikenal sebagai etnomatematika, Hal ini pertama kali diperkenalkan oleh matematikawan asal brazil yang bernama D'Ambrosio pada tahun 1977. Etnomatematika merupakan suatu program yang memiliki tujuan untuk mempelajari bagaimana siswa menggunakan ide matematika untuk menyelesaikan dan memecahkan problem yang berkaitan dengan kehidupan keseharian (Rahmawati Z \& Muchlian, 2019). Lebih lanjut Mahendra (2017) mengatakan etnomatematika sendiri mengadopsi konsep matematika secara luas yang berkaitan dengan kegiatan, berhitung, mengukur, merancang bangunan atau alat, membuat grafik. Dengan menerapkan pembelajaran berbasis etnomatika, suasana belajar akan menyenangkan bagi peserta didik dan pendidik, yang memungkinkan peserta didik dan pendidik berpartisipasi aktif berdasarkan budaya yang sudah mereka kenal (Sarwoedi et al., 2018) .

Kajian etnomatematika ini telah dilakukan pada kebudayaanan seluruh dunia, salah satunya budaya yang ada di Bali. Etnomatematika pada budaya bali dapat dijumpai pada kalender bali, ukiran bali, metode yang digunakan oleh tukang bahan bangunan di Bali, dan bahan - bahan banten maupun sesajen yang dibuat oleh masyarakat bali dalam sehari - hari seperti tamas, ceper, segehan ituk - ituk, tumpeng, daksina, klakat, tempeh dll. Berdasarkan paparan tersebut dapat dirangkum etnomatematika adalah kajian kebudayaan untuk mengenali unsur matematika yang terdapat dalam kebudayaan tersebut yang dapat digunakan dalam pembelajaran matematika

Berdasarkan pemaparan tersebut, maka dilakukan penelitian yang berjudul "Pengaruh Model Pembelajaran Probing Prompting berbasis etnomatematika terhadap kompetensi pengetahuan Matematika kelas V". Tujuan dilaksanakan penelitian ini adalah untuk mengetahui pengaruh yang signifikan model pembelajaran Probing Prompting berbasis Etnomatematika terhadap kompetensi pengetahuan Matematika kelas V SD Gugus Letda Made Putra Kecamatan Denpasar Utara Tahun Ajaran $2019 / 2020$.

\section{METODE}

Penelitian ini berjenis eksperimen semu dengan rancangan penelitian Non Equivalent Pretest Postest Control Group Design. Penelitian ini dilaksanakan di SD Gugus Letda Made Putra Kecamatan Denpasar Utara pada semester genap tahun ajaran 2019/2020. Populasi dalam penelitian ini adalah seluruh kelas $\mathrm{V}$ dengan banyak kelas 13 jumlah 462 orang. Teknik pengambilan sampel dalam pen elitian ini menggunakan teknik Cluster Random Sampling, dengan kriteria yang dimaksudkan yaitu pengacakan individu tidak dapat dilakukan dikarenakan peneliti tidak bisa untuk mengubah kelas yang telah dibentuk sebelumnya, selanjutnya kelas-kelas tersebut diundi untuk mendapatkan 2 kelas. Dengan teknik tersebut diperoleh sampel yaitu kelas Vв SD Negeri 23 Dangin Puri sebagai kelompok kontrol dan kelas V SD Negeri 2 Tonja sebagai kelompok eksperimen.

Kegiatan penelitian ini terdiri dari 3 tahap. Berikut penjabaran dari masing - masing tahapan tersebut. (1) Tahap Awal, pada tahapan ini yang dilaksanakan, yakni : (a) Melaksanakan kegiatan observasi dan wawancara di SD tempat yang akan dilaksanakan penelitian, (b) Menentukan sampel pada penelitian, (c) Mengkonsultasikan materi bersama wali kelas terkait, (d) Mengkonsultasikan instrumen yang nantinya digunakan dalam proses pengumpulan data (pretest dan posttest) dengan dospem dan wali kelas terkait, (e) Dengan menggunakan teknik cluster random sampling dilakukan kegiatan menentukan kelompok sampel penelitian, (f) Memberikan pretest pada sampel yang terpilih. Setelah itu menyetarakan kelompok dengan menganalisis data pretest dengan uji-t, (g) Setelah sampel dinyatakan setara, kemudian sampel diundi kembali agar dapat menentukan kelompok kontrol dan eksperimen. (2) Tahap Proses, pada tahapan ini yang dilaksanakan, yakni : (a) Kelompok eksperimen menerima treatment sebanyak 6x dengan menerapkan Model pembelajaran Probing Prompting berbasis Etnomatematika kemudian di lain hal kelompok kontrol secara konvensional dibelajarkan sebanyak enam kali berturut - turut disesuaikan dengan jadwal yang telah disepakati, (b) Melakukan posttest guna mendapatkan data kompetensi pengetahuan. (3) Tahap Akhir, pada tahapan ini yang dilaksanakan, yakni menganalisis data hasil pretest dan posttest guna mengetahui perbedaan di setiap kelompok

Penelitian ini terdiri dari variabel bebas yakni model pembelajaran probing prompting berbasis etnomatematika, diterapkan pada kelompok eksperimen. Sementara variabel terikat yaitu kompetensi pengetahuan matematika. Untuk menentukan kompetensi pengetahuan matematika, Instrumen yang digunakan yaitu tes objektif pilihan ganda. Instrumen penelitian dikembangkan berpatokan pada kisikisi, kompetensi pengetahuan matematika yang diukur sebatas pada tingkat kognitif C1-C4 yang 
meliputi Pengetahuan, Pemahaman, Penerapan, Analisis. Sebelum tes digunakan, dilakukan coba instrumen berupa uji validitas isi serta butir, uji IK, uji DB, dan uji reliabilitas.

Pada uji validitas isi dilakukan dengan menyusun soal sesuai dengan kisi - kisi serta materinya sesuai dengan kurikulum. Penyusunan kisi - kisi harus sesuai dengan bahan pelajaran dalam penelitian yakni materi bangun ruang, sedangkan pada uji validitas butir tes dengan banyak soal 40 soal yang diuji menggunakan cara Korelasi Product Moment yang diujikan pada kelas VI SDN 2 Tonja dengan banyak siswa adalah 38 orang dan diperoleh sebanyak 28 butir soal yang valid dan 12 butir soal yang tidak valid kemudian dilakukan pengujian IK. Berdasarkan perhitungan IK butir tes didapat 6 soal dalam kategori sukar, 16 soal dalam kategori sedang dan 6 soal dalam kategori mudah. Selanjutnya dilakukan pengujian DB dan diperoleh 4 soal dalam kategori cukup, 22 soal dalam kategori baik, dan 2 soal dalam kategori baik sekali. Pengujian instrumen terakhir yaitu uji reliabilitas dengan hasil pengujian yaitu instrumen pada penelitian ini tergolong reliable.

Setelah melakukan uji coba instrumen, barulah instrumen kompetensi pengetahuan matematika dapat digunakan dengan jumlah butir soal sebanyak 28 soal, Jika peserta didik mampu menjawab benar maka diberikan skor 1 dan jika salah maka diberikan skor 0. Skor dari setiap butir soal tersebut dijumlahkan sehingga diperoleh nilai kompetensi pengetahuan matematika. Adapun rentangan skor yang diperoleh oleh peserta didik yaitu 28 sebagai skor maksimum dan 0 sebagai skor minimum.

Setelah memperoleh data kompetensi pengetahuan matematika, kemudian dicari rerata, Standar deviasi beserta varians selanjutnya data tersebut dideskripsikan dengan mengkonversikan ke dalam penilaian acuan norma (PAN) dengan skala 5. Langkah selanjutnya menentukan Gain Skor (GSn) yang diperoleh dari selisih hasi posttest dengan pretest. Setelah diperoleh GSn yang diperlukan terkumpul, maka langkah selanjutnya adalah melakukan uji hipotesis, teknik analisis data yang digunakan adalah statistik inferensial dengan uji-t, sebelum menganalisis data, dilakukan uji prasyarat terlebih dahulu yakni uji normalitas dan homogenitas.

Uji normalitas yang bertujuan untuk mengetahui apakah uji hipotesis dengan statistik parametrik dapat dilakukan atau tidak. Apabila sebaran data sudah berdistribusi normal, maka uji lanjut dengan menggunakan statistik parametrik dapat dilakukan. Dan jika sebaliknya dilanjutkan dengan menggunakan statistik nonparametrik (Wahyudi David, 2018). Untuk mengetahui apakah sebaran data berdistribusi normal atau tidak menggunakan uji Kolmogorov Smirnov (KS), adapun kriteria dari pengujian KS yaitu pada tingkat kesalahan 0,05 jika nilai maksimum $\left|F_{r}-F_{S}\right| \leq$ nilai $K S$ tabel, maka data berdistribusi normal \& sebaliknya (Cahyono, 2015)

Uji prasyarat analisis data selanjutnya yaitu uji homogenitas varians bertujuan untuk menguji apakah sebaran data homogen atau tidak, yaitu dengan membandingkan variansnya. Uji homogenitas dapat dilakukan apabila kelompok data tersebut dalam distribusi normal (Wahyudi David, 2018). Adapun uji homogenitas yang digunakan dalam penelitian ini adalah uji Fisher (Uji F), adapun kriteria dari pengujian Uji F yaitu jika $F_{h i t} \leq F_{t a b}$ maka sampel homogen. Pengujian dilakukan pada tingkat kesalahan 0,05 dengan $\mathrm{df}_{\text {pembilang }}=\mathrm{n}_{1}-1$ dan $\mathrm{df}_{\text {penyebut }}=\mathrm{n}_{2}-1$ (Sugiyono, 2018)

Jika data telah memenuhi prasyarat, selanjutnya dilakukan uji hipotesisnya menggunakan uji-t dengan kriteria pengujian pada tingkat kesalahan 0,05 dengan $d k=n_{1}+n_{2}-2$. Jika nilai $t_{\text {hit }} \leq t_{\text {tab }}$, maka $\mathrm{H}_{0}$ diterima \& sebaliknya (Sugiyono, 2018)

\section{HASIL DAN PEMBAHASAN}

Berdasarkan hasil penelitian yang telah dilakukan, berikut data hasil posttest kompetensi pengetahuan matematika disajikan dalam bentuk diagram polygon pada gambar 1 .

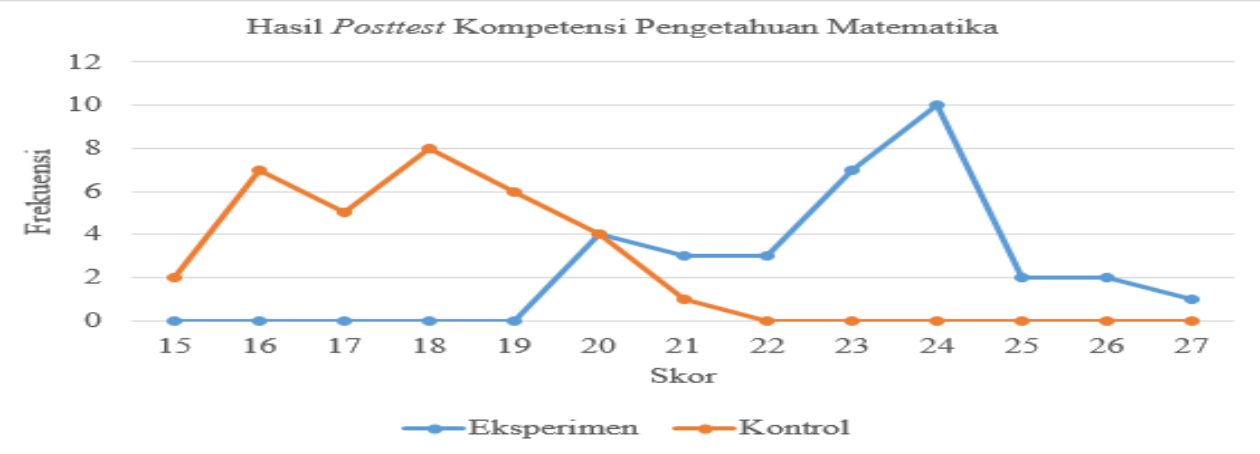

Gambar 1. Hasil Posttest Kompetensi Pengetahuan Matematika 
Berdasarkan gambar 1. diperoleh hasil posttest kompetensi pengetahuan matematika kelompok eksperimen berupa rerata sebesar 23,094, Standar Deviasi sebesar 1,792, varians sebesar 3,211 serta skor terendah dan tertinggi masing - masing sebesar 20 dan 27. Sedangkan hasil posttest kompetensi pengetahuan matematika kelompok kontrol berupa rerata sebesar 17,758, Standar Deviasi sebesar 1,558, varians sebesar 2,427 serta skor terendah dan tertingginya sebesar 15 dan 21.

Nilai rerata posttest kelompok eksperimen lebih dari dibandingkan kontrol. Berdasarkan kriteria PAN skala 5, rerata eksperimen dan rerata kontrol mendapatkan predikat Cukup. Hal ini disebabkan karena beberapa faktor antara lain pendidik yang bertugas pada kelompok eksperimen dan kontrol memiliki gelar yang sama yakni S.Pd, sumber belajar yang digunakan oleh siswa sama yaitu buku Tema dan buku LKS, serta pendekatan yang digunakan dalam proses pembelajaran sama - sama menggunakan pendekatan saintifik (5 M).

Uji prasyarat yang meliputi uji normalitas dan homogenitas dilakukan sebelum melaksanakan uji hipotesis (Sugiyono, 2018). Uji normalitas dilakukan pada kedua kelompok. Dalam uji normalitas digunakan analisis uji Kolmogorov Smirnov (KS) dengan tingkat kesalahan 0,05. Hasil uji KS yang dilakukan pada kelompok eksperimen diperoleh nilai maksimum $\mid \mathrm{Ft}$-Fs $\mid<$ nilai $K S$ tabel $(0,116949<$ 0,234), sedangkan hasil uji KS yang dilakukan pada kelompok kontrol diperoleh nilai maksimum |Ft-Fs| $<$ nilai $K S$ tabel $(0,143368<0,231)$ ini memiliki arti bahwa sebaran data GnS kompetensi pengetahuan matematika kelompok eksperimen \& kontrol berdistribusi normal.

Uji homogenitas varian dilakukan pada kelompok eksperimen yang banyaknya 32 orang dan kelompok kontrol yang banyaknya 33 orang. Uji homogenitas varian untuk kedua kelompok digunakan uji Fisher dengan tingkat kesalahan 0,05 serta $\mathrm{df}_{\text {pembilang }}: 32-1=31$ dan $\mathrm{df}_{\text {penyebut }}: 33-1=32$. Hasil uji $\mathrm{F}$ diperoleh $\mathrm{F}_{\text {hit }}<\mathrm{F}_{\text {tab }}(1,286<1,810)$ ini bermakna data GSn kompetensi pengetahuan matematika bersifat homogen.

Hipotesis penelitian yang diuji adalah Ho yang berbunyi Tidak terdapat perbedaan yang signifikan kompetensi pengetahuan matematika antara kelompok yang dibelajarkan menggunakan model pembelajaran Probing Prompting berbasis Etnomatematika dengan kelompok yang dibelajarkan menggunakan pembelajaran konvensional pada kelas V SD Gugus Letda Made Putra Kecamatan Denpasar Utara Tahun Ajaran 2019/2020. Hasil analisis uji hipotesis menggunakan teknik uji-t dapat dilihat pada tabel 1.

Tabel 1. Tabel Uji Hipotesis

\begin{tabular}{lccccccc}
\hline \multicolumn{1}{c}{ Kelompok } & $\mathbf{n}$ & $\mathbf{D f}$ & $\overline{\boldsymbol{X}}$ & $\mathbf{s}^{\mathbf{2}}$ & $\mathbf{t}_{\text {hit }}$ & $\mathbf{t}_{\text {tab }}$ & Simpulan \\
\hline Eksperimen & 32 & \multirow{2}{*}{63} & 0,729 & 0,009 & \multirow{2}{*}{12,696} & \multirow{2}{*}{1,998} & \multirow{2}{*}{ Ho ditolak } \\
Kontrol & 33 & & 0,447 & 0,007 & & & \\
\hline
\end{tabular}

Berdasarkan tabel 1 menunjukkan bahwa $t_{\text {hit }}=12,696$ dan $t_{\text {tab }}=1,998$ untuk $\mathrm{df}=63$. Ini berarti $t_{\text {hit }}(12,696)<t_{\text {tab }}(1,810)$. sehingga $H_{0}$ ditolak. Ini artinya terdapat perbedaan yang signifikan kompetensi pengetahuan matematika antara kelompok yang dibelajarkan menggunakan model pembelajaran Probing Prompting berbasis Etnomatematika dengan kelompok yang dibelajarkan menggunakan pembelajaran konvensional pada kelas V SD Gugus Letda Made Putra Kecamatan Denpasar Utara Tahun Ajaran 2019/2020. Hal tersebut membuktikan bahwa model PP berbasis etnomatematika memberikan pengaruh dan dampak yang baik terhadap kompetensi pengetahuan peserta didik dalam bidang matematika. Peserta didik dituntut untuk berfikir aktif dan berani menyampaikan pendapatnya serta menjawab pertanyaan yang diberikan oleh pendidik sehingga akan mengarah pada proses pembelajaran yang bermakna, hal tersebut merupakan salah satu keunggulan dari model $P P$.

Bersumber dari hasil pengamatan yang telah dilaksanakan selama penelitian ini berlangsung, pembelajaran pada kelas eksperimen yang diterapkan model $P P$ berbasis Etnomatematika siswa menjadi semakin antusias dalam pembelajaran dibandingkan sebelum diterapkannya model ini selain itu proses belajar mengajar menjadi lebih efektif, kondisif serta maksimal sehingga mampu meningkatkan keaktifan, motivasi, dan kreativitas dan kepercayaan peserta didik dalam belajar matematika sehingga kemampuan kompetensi pengetahuan menjadi lebih baik, Hal ini sesuai dengan pendapat Novena \& Kriswandani (2018) model pembelajaran probing prompting membantu siswa dalam aktif berpikir, berdiskusi pendapat yang berbeda, dan memberi kesempatan untuk menanyakan 
hal - hal yang kurang jelas. Proses pembelajaran menggunakan model probing prompting peran guru hanya memberi pertanyaan - pertanyaan untuk menuntun dan menggali pengetahuan siswa mengingat konsep lama yang akan dihubungkan pada konsep baru. Proses pembelajaran tanya jawab seperti ini membutuhkan keyakinan diri pada siswa untuk menjawab setiap pertanyaan. Hal tersebut sejalan dengan pendapat (Mustika \& Buana, 2017) pada model pembelajaran PP ini peserta didik dituntut untuk aktif dalam berfikir dalam proses pembelajaran sehingga dapat melejitkan proses berpikir yang mampu mengaitkan pengetahuan dan pengalaman siswa dengan pengetahuan baru yang sedang dipelajari dan juga peserta didik harus berkonstrasi penuh supaya dapat menyelesaikan soal - soal yang diberikan oleh pendidik. Selain itu menurut Kencanawaty \& Iriawan (2017) pembelajaran berbasis kebudayaan mampu meningkatkan kemampuan peserta didik dalam menjawab soal maupun tugas yang diberikan oleh pendidik dengan baik dan benar sehingga mampu meningkatkan hasil belajar siswa

Proses pembelajaran $P P$ berbasis Etnomatematika mengarah pada student centered yang setiap kegiatan pembelajarannya pendidik menyuguhkan serangkaian pertanyaan yang bersifat menuntun yang menyebabkan terjadinya kegiatan berpikir yang menggabungkan pengalaman serta pengetahuan yang sedang dipelajari, dimana saat kegiatan belajar mengajar pendidik membawa salah satu bentuk kebudayaan di sekitar peserta didik yang memiliki unsur matematika untuk menambah pemahaman peserta didik tentang materi pelajaran yang dibelajarkan. Etnomatematika yang digunakan dalam proses pembelajaran matematika dalam materi volume bangun ruang khususnya bangun kubus dan balok adalah keben yang berbentuk kubus dan balok. Tahapan ataupun sintaks pada model pembelajaran ini memiliki 7 fase (tahapan).

Pembelajaran dimulai dari Fase ke-1, pada tahapan ini pendidik menjelaskan tentang kebudayaan lokal yang ada di bali untuk meningkatkan pengetahuan peserta didik sedangkan peserta didik menyimak penjelasan pendidik. Fase ke-2, pendidik memberikan kesempatan kepada peserta didik untuk bertanya terkait budaya yang dijelaskan. Fase ke-3, Pendidik menyajikan serangkaian pertanyaan yang berkaitan dengan kehidupan sehari-hari terkait dengan budaya lokal bali mengenai indikator yang dibelajarkan dan peserta berdiskusi dengan teman dalam kelompok kecil guna memecahkan serangkaian pertanyaan tersebut. Fase ke-4, Pendidik memberikan kesempatan kepada peserta didik untuk mengerjakan serangkaian pertanyaan mengenai indikator yang dibelajarkan dan peserta didik mengerjakan permasalahan yang diberikan pendidik mengenai indikator yang dibelajarkan dengan berdiskusi. Fase ke-5, Pendidik menunjuk beberapa peserta didik untuk menyelesaikan serangkaian pertanyaan yang diberikan dan peserta didik yang ditunjuk oleh pendidik, menyelesaikan serangkaian pertanyaan yang diberikan. Fase ke-6, Apabila yang disampaikan peserta didik tepat, selanjutnya peserta didik lain memberikan tanggapan. Hal tersebut dilaksanakan guna mengetahui keikutsertaan siswa dalam belajar. Namun, jika jawaban peserta didik kurang tepat, tidak tepat atau diam maka peserta didik diberikan pertanyaan lain yang jawabannya merupakan petunjuk penyelesaian persoalan. Lalu peserta didik lain juga diberikan pertanyaan lain guna mengetahui keterlibatan seluruh siswa ketika proses pembelajaran dan peserta didik menyampaikan tanggapan terhadap pertanyaan yang diberikan oleh pendidik. Fase ke-7, peserta didik diberikan pertanyaan akhir mengenai indikator yang dibelajarkan serta terkait dengan budaya lokal yang ada di Bali dan peserta didik mengerjakan pertanyaan akhir yang diberikan oleh pendidik.

Sedangkan pembelajaran pada kelompok kontrol kurang optimal, karena selama kegiatan pembelajaran pendidik lebih aktif dalam menyampaikan materi sehingga partisipasi siswa di kelas kurang. Pembelajaran di kelas kurang melibatkan siswa dan pendidik lebih sering memberikan ceramah dan lebih mementingkan hasil dibandingkan dengan proses. Siswa lebih sering diajak untuk berlatih dan menyelesaikan soal-soal yang diberikan oleh guru sehingga menyebabkan kompetensi pengetahuan matematika peserta didik belum maksimal. Adapun tahapan proses pembelajaran pada kelompok kontrol yakni Pertama, Pendidik menyajikan informasi yang berhubungan dengan materi. Kedua, Pendidik menyodorkan contoh soal yang berhubungan dengan materi. Ketiga, Pendidik menyodorkan latihan soal kepada peserta didik. Keempat, Peserta didik ditugaskan untuk menyelesaikan soal yang diberikan oleh Pendidik. Kelima, Pendidik menunjuk siswa secara bergiliran untuk mengerjakan soal yang ditugaskan. Keenam, Pendidik mereview jawaban yang dikerjakan oleh peserta didik.

Hasil penelitian ini juga didukung oleh penelitian : (a)Kartika (2019) menyimpulkan bahwa Model Pembelajaran PP berbantuan Media Video berpengaruh terhadap hasil belajar IPA kelas V. (b) (Adnyani, 2020) menyimpulkan bahwa pendekatan CTL Berbasis Etnomatematika berpengaruh terhadap kompetensi pengetahuan matematika siswa kelas IV. (c) Karwati (2018) menyimpulkan 
bahwa Model Pembelajaran PP berbantuan Multimedia berpengaruh terhadap hasil belajar IPA kelas V. (d) (Febriani et al., 2019) menyimpulkan bahwa terdapat Pengaruh Pembelajaran Matematika Realistik Berbasis Etnomatematika Terhadap Kemampuan Pemahaman Konsep Matematika Siswa

Pada penelitian ini dapat memberikan implikasi terhadap pembelajaran di SD. Implikasi secara teoritis Pemilihan model yang tepat sehingga mempengaruhi kompetensi matematika siswa. Penelitian ini membuktikan model $P P$ berbasis etnomatematika baik untuk diterapkan dalam meningkatkan hasil belajar matematika peserta didik. Dengan ini dapat membuat siswa termotivasi, selalu siap saat pembelajaran, aktif dan tidak terasa bosan. Sedangkan implikasi secara praktis Hasil penelitiannya dapat dijadikan bahan untuk guru ketika memilih variasi model dalam mengajar, seperti menerapkan model $P P$ berbasis etnomatematika dalam pelajaran matematika dikarenakan sudah terbukti dapat memberikan dampak bagi kompetensi pengetahuan matematika peserta didik menjadi meningkat dari belajar secara konvensional.

\section{SIMPULAN}

Berdasarkan hasil pengujian dan pembahasan dari data yang diperoleh maka dapat disimpulkan bahwa Terdapat pengaruh yang signifikan model pembelajaran Probing Prompting berbasis etnomatematika terhadap kompetensi pengetahuan matematika kelas V SD Gugus Letda Made Putra Kecamatan Denpasar Utara Tahun Ajaran 2019/2020. Berdasarkan hasil penelitian,Adapun saran yang disampaikan untuk berbagai pihak yaitu: saran kepada (1) Siswa, belajar matematika dengan model ini menjadi lebih bermakna karena materi lebih mudah untuk dipahami, sehingga disarankan agar peserta didik lebih giat mengikuti pembelajaran dikelas (2) Guru, disarankan dari hasil penelitian ini pendidik mampu melaksanakan inovasi pembelajaran yang baru dalam kegiatan belajar mengajar, sehingga proses pembelajaran lebih menyenangkan dan bermakna serta mampu meningkatkan prestasi belajar peserta didik. (3) Kepala Sekolah, disarankan dari hasil penelitian ini pimpinan sekolah mampu memeberikan stimulus dan semangat kepada para pendidik agar mampu meningkatkan kualitas kegiatan belajar mengajar di dalam kelas sehingga mampu mencetak output yang dapat bersaing serta berkualitas. (4)kepada peneliti lainnya, disarankan dari hasil penelitian ini dapat digunakan untuk bahan acuan untuk penelitian berikutnya

\section{DAFTAR PUSTAKA}

Adnyani, I. N. W. (2020). Pengaruh Model Pembelajaran ( VAK ) Berbasis Whole Brain Teaching Terhadap Kompetensi Pengetahuan IPA. MIMBAR PGSD Undiksha, 8(1).

Arta, I. M. (2020). Problem Based Learning Berbantuan Icebreaker Berpengaruh Terhadap Kemampuan Pemecahan Masalah Matematika. MIMBAR PGSD Undiksha, 8(2).

Aulia, D. S. (2019). Penerapan Model Pembelajaran Probing Prompting Untuk Meningkatkan Motivasi Belajar Matematika Peserta Didik Kelas VIII F SMP NEGERI 1 Babadan. Jurnal Ilmiah Mahasiswa, 53(9). https://doi.org/10.1017/CB09781107415324.004

Cahyono. (2015). Statistik Uji Normalitas. Yayasan Sanitarian Banyumas.

Dewi, E. R. (2018). Metode Pembelajaran Modern Dan Konvensional Pada Sekolah Menengah Atas. Jurnal Ilmu Pendidikan, 2(1). https://doi.org/10.26858/pembelajar.v2i1.5442

Febriani, P., Widada, W., \& Herawaty, D. (2019). Pengaruh Pembelajaran Matematika Realistik Berbasis Etnomatematika Terhadap Kemampuan Pemahaman Konsep Matematika Siswa SMA Kota Bengkulu. Jurnal Pendidikan Matematika Raflesia, 04(02), 120-135.

Fitrianti, I. (2020). Keefektifan Media Magic Box Terhadap Hasil Belajar Matematika Materi Jaring-Jaring Bangun Ruang Sederhana. MIMBAR PGSD Undiksha, 8(2).

IEA. (2015). TIMSS 2015 International Results in Mathematics.

Indrawan, I. K. M. A. (2018). Peningkatan Prestasi Belajar Matematika Siswa Melalui Pembelajaran ARIAS Berbantuan Geogebra. Jurnal Pendidikan Dan Pembelajaran Matematika Indonesia, 7(1), 7985. https://doi.org/10.21067/jbpd.v2i1a.2353

Jayanti. (2018). Pembelajaran Menggunakan Teknik Probing Prompting Berbantuan Edmodo Blended Learning Pada Materi Persamaan Diferensial Matematis Mahasiswa Di Universitas Pgri Palembang. Journal of Chemical Information and Modeling, 5(9). https://doi.org/10.1017/CB09781107415324.004

Kartika, N. W. S. D. (2019). Pengaruh Model Pembelajaran Probing Prompting Berbantuan Multimedia Terhadap Hasil Belajar Ipa. Indonesian Journal of Educational Research and Review, 2(2). https://doi.org/10.23887/jppp.v2i2.15386 
Karwati, N. P. R. K. (2018). Pengaruh Model Pembelajaran Probing-Prompting Berbantuan Media Sederhana Terhadap Hasil Belajar IPA. Jurnal Ilmiah Sekolah Dasar, 2(3). https://doi.org/10.23887/jisd.v2i3.16148

Kencanawaty, G., \& Iriawan, A. (2017). Penerapan Etnomatematika dalam Pembelajaran Matematika di Sekolah Berbasis Budaya Gita. Universitas Indraprasta PGRI, Jakarta, 27.

Krisnayanti, N. K. D., Wiarta, I. W., \& Negara, I. G. A. O. (2017). Pengaruh Model Pembelajaran Inkuiri Terbimbing Berbantuan Tutor Sebaya Terhadap Kompetensi Pengetahuan Matematika Siswa Kelas V. E-Journal PGSD Universitas Pendidikan Ganesha, 5(2).

Kurniyanthi, N. M. F. (2017). Pengaruh Model Pembelajaran Kooperatif Tipe Snowball Throwing Berbantuan Lagu Daerah Terhadap Kompetensi Pengetahuan Matematika Universitas Pendidikan Ganesha. E-Journal PGSD Universitas Pendidikan Ganesha, 5(2).

Mahendra, I. W. E. (2017). Project Based Learning Bermuatan Etnomatematika Dalam Pembelajar Matematika. JPI (Jurnal Pendidikan Indonesia), 6(1), 106-114. https://doi.org/10.23887/jpiundiksha.v6i1.9257

Megasari, M., Sundaryono, A., \& Firdaus, M. L. (2018). Pembelajaran probing prompting untuk meningkatkan berpikir kritis siswa anggota kelompok ilmiah remaja. PENDIPA Journal of Science Education, 2(2), 163-169. https://doi.org/10.33369/pendipa.2.2.163-169

Mustika, H., \& Buana, L. (2017). Penerapan Model Pembelajaran Probing Prompting Terhadap Kemampuan Pemecahan Masalah Matematika Siswa Helma. MES Uournal of Mathematics Education and Science), 2(2).

Muthmainnah, M., Hapizah, H., \& Somakim, S. (2019). Penerapan Strategi Probing Prompting Dalam Pembelajaran Matematika Materi Relasi Dan Fungsi Di Smp. Lentera Sriwijaya: Jurnal Ilmiah Pendidikan Matematika, 1(1), 27-38. https://doi.org/10.36706/jls.v1i1.9567

Novena, V. V., \& Kriswandani, K. (2018). Pengaruh Model Pembelajaran Probing Prompting Terhadap Hasil Belajar Ditinjau Dari Self-Efficacy. Scholaria: Jurnal Pendidikan Dan Kebudayaan, 8(2). https://doi.org/10.24246/j.js.2018.v8.i2.p189-196

Permendikbud. (2016). ). Peraturan Menteri Pendidikan dan Kebudayaan Republik Indonesia Nomor 24 Tahun 2016 Tentang Kompetensi Inti dan Kompetensi Dasar Pelajaran Pada Kurikulum 2013 Pada Pendidikan Dasar dan Pendidikan Menengah.

Purnamasari, I. D. A. A. D. (2018). Pengaruh Model Pembelajaran Kooperatif Teknik Tutor Sebaya Terhadap Sikap Dan Prestasi Belajar Matematika Siswa Kelas X Program Keahlian Teknik Komputer dan Jaringan Smk Negeri 3 Singaraja. Jurnal Pendidikan Dan Pembelajaran Matematika Indonesia, 7(2). https://doi.org/10.29333/aje.2019.423a

Putra, I. K. D. A. S., Margunayasa, I. G., \& Wibawa, I. M. C. (2017). Pengaruh Model Pembelajaran Inkuiri Terbimbing Berbantuan Peta Pikiran terhadap Hasil Belajar IPA Kelas V SD. Jurnal Pendidikan, 5(2).

Putu, N., \& Dewi, J. (2020). Metode Pembelajaran Drill Berbasis Masalah Kontekstual Terhadap Kompetensi Pengetahuan Matematika. MIMBAR PGSD Undiksha, 8(2).

Rahmawati Z, Y. R., \& Muchlian, M. (2019). Eksplorasi Etnomatematika Rumah Gadang Minangkabau Sumatera Barat. Jurnal Analisa, 5(2), 123-136. https://doi.org/10.15575/ja.v5i2.5942

Sarwoedi, S., Marinka, D. O., Febriani, P., \& Winre, I. N. (2018). Efektifitas Etnomatematika dalam Meningkatkan Kemampuan Pemahaman Matematika Siswa Pendahuluan Pengertian Etnomatematika. Jurnal Pendidikan Matematika Raflesia, 03(02), 101-106.

Shoimin. (2017). 68 Model Pembelajaran Inovatif Dalam Kurikulum 2013. Ruzz Media.

Sugiyono. (2018). Statistika Untuk Penelitian. Alfabeta.

Susanti, E. (2017). Penerapan Model Pembelajaran Probing-Prompting untuk Meningkatkan Kemampuan Berpikir Kritis Matematis Siswa Kelas XI.I PA MAN 1 KOTA Bengkulu. Jurnal Pendidikan Matematika Raflesia, 53. https://doi.org/10.1017/CB09781107415324.004

Susanto. (2019). Teori Belajar Dan Pembelajaran Di Sekolah Dasar. Prenamedia Group.

Yulia, P., \& Ningsih, S. U. (2018). Pengaruh Penerapan Model Pembelajaran Probing Prompting dan Contextual Teaching and Learning Terhadap Hasil Belajar Ditinjau dari Motivasi Belajar Siswa Sekolah Menengah Kejuruan. Edumatika: Jurnal Riset Pendidikan Matematika, 1(1), 56. https://doi.org/10.32939/ejrpm.v1i1.218 